34. Kg2 Kb6 35. Bd3 Kc5 36. a3 f5 37. Ne2 Nb3 38. Kg3 g6 39. Ng1 Nc1 40. Bc2 Bc4 41. Bd1 Kd4 42. Nf3+ Kc3 43. Kh4 Nd3 44. Be2 Nxf2 45. Bxc4 Kxc4 46. Ng5 Nd3 47. Nxh7 Nxf4 48. Kg5 1/2

B. Tsoekkerman - Mephisto RISC 1 MB (NicKey QP 6.1.1)

1. d4 d5 2. Nf3 Nf6 3. e3 e6 4. Bd3 c5 5. b3 Nc6 6. Bb2 Bd6 7. Ne5 cxd4 8. exd4 O-O 9. a3 Bd7 10. Nd2 Qc7 11. Qe2 Rac8 12. O-O Qb6 13. Ndf3 Rfe8 14. Rad1 h6 15. Kh1 a5 16. Rg1 Rc7 17. g4 Rec8 18. g5 hxg5 19. Nxg5 Nd8 20. Qf3 Be7 21. Nh7 Nxh7 22. Bxh7+ Kxh7 23. Qh5+ Kg8 24. Rxg7+ Kxg7 25. Rg1+ Bg5 26. Qxg5+ Kf8 27. a4 Qb4 28. Bc1 Qxd4 29. Ba3+ Qb4 30. Bxb4+ axb4 31. h4 Be8 32. h5 Rc3 33. h6 Rh3+ 34. Kg2 Rxh6 35. Qxh6+ 1-0

\title{
CALENDAR OF COMPUTER-CHESS EVENTS
}

For the benefit of readers wishing to enter programs in computer-chess competitions or to attend, we list future events. Organizers are invited to send full details to the Editor for inclusion in the calendar.

\section{2}

\section{November 23-27}

The $7^{\text {th }}$ World Computer-Chess Championship, to be held in Madrid, Spain.

Details: David Levy, 89, Constantine Road, London NW3 2LP, UK.

[See also pages 96-98 of the June 1992 issue and pages 170-172 of this issue.]

1993

May 5-7, 10-12

The 1993 AEGON Man-Computer Tournament, to be held in The Hague, The Netherlands.

Details: Cock de Gorter, Valkenboskade 607, 2563 JE The Hague, The Netherlands.

\section{July 1-2}

The Advances in Computer Chess 7 conference, to be held in Maastricht, The Netherlands.

Details: Jaap van den Herik, Department of Computer Science, University of Limburg, P.O. Box 616, 6200 MD Maastricht, The Netherlands.

[See also page 174 of this issue.]

\section{August 2-6}

Uniform Platform Computer-Chess Tournament, to be held in London, UK.

Details: Don Beal, Department of Computer Science, Queen Mary and Westfield College, Mile End Road, London E1 4NS, UK.

[See also pages 173-174 of this issue.]

\section{August 15-28}

The $1^{\text {st }}$ Mind Sports Olympiad, including the $5^{\text {th }}$ Computer Olympiad. To be held in London, UK. Details: David Levy, 89, Constantine Road, London NW3 2LP, UK.

\section{MORE INFORMATION ON
THE $7^{\text {th }}$ WORLD COMPUTER-CHESS CHAMPIONSHIP}

Madrid, November 23-27, 1992

David Levy

As previously announced, the $7^{\text {th }}$ World Computer-Chess Championship will take place in the Spanish capital in late November. The idea for holding our most important tournament in Spain during the $500^{\mathrm{h}}$ anniversary year of the discovery of the New World was suggested as long ago as 1987 by Amador Cuesta. His idea was taken up with great enthusiasm by the leading Spanish chess journalist, Leontxo Garcia, who writes on chess news for El Pais and is responsible for many of the chess programmes which appear on Spanish television. Leontxo worked tirelessly for more than 2 years in order to find a way to have the championship sponsored in 
Spain. Eventually he found a public relations company, DOXA, whose President, Guillermo Bosovsky, had the confidence to take it upon his company to guarantee the US $\$ 80,000$ required to host the tournament. Last year, on November $5^{\text {th }}$, I went to Madrid at DOXA's invitation to sign the sponsorship contract on behalf of the ICCA.

Guillermo Bosovsky's confidence in the event was justified by the interest shown by Madrid's Polytechnic University which has generously provided the sponsorship money. Their School of Informatics is home to the world's first chess computers, the two machines designed and built around the turn of the century by the great Spanish inventor Leonardo Torres y Quevedo. Torres' machines played the ending of King and Rook v King using a simple but effective rule-based system which could always force checkmate against any defence. These machines are housed in the museum in the Informatics Department along with a number of Torres' other fascinating inventions. An exhibition of these devices is being staged during the toumament and the University is hoping to have at least one of the chess machines in working order by the time our toumament begins.

The full address of the playing site for the World Championship is:

Universidad Polítecnica de Madrid Escuela Universitaria de Informática

Km. 7 Carretera Valencia 28031 Madrid

The playing schedule allows for 5 rounds, which will be played from 16:00 to 22:00 (at the latest) each day. The rate of play will be 40 moves in 2 hours followed by 20 moves in the next hour. Unfinished games will be adjudicated. The Tournament Director will be Mike Valvo.

It has been customary for the ICCA to invite an Honoured Guest to attend our triennial World Championship. I am delighted to announce that this year Richard Greenblatt has graciously agreed to be our guest. Richard was the author of the famous MacHack VI program which created history by being the first program to compete in a (human) chess tournament. His paper (written with Eastlake and Crocker): The Greenblatt Chess Program was published 25 years ago and represents a milestone in the annals of computer chess. During the paper session in Madrid Richard will be talking about his experiences of competing with a program 25 years ago.

The provisional schedule of events is as follows:

November $21^{\text {st }}-22^{\text {nd. }}: \quad$ Arrival of participants and officials

November $23^{\text {rd }}$ : Opening ceremony, 14:00

$1^{\text {st }}$ round, 16:00-22:00

November 24 $\quad$ Excursion to El Escorial, 09:00

$2^{\text {nd }}$ round, 16:00-22:00

November $25^{\text {th }}: \quad$ ICCA Meeting, 14:00

$3^{\text {rd }}$ round, 16:00-22:00

November $26^{\text {th }}$ : $\quad$ Excursion to Toledo, early start

$4^{\text {th }}$ round, 16:00-22:00

November $27^{\text {th }}$ : Paper session, 10:00-12:30

$5^{\text {th }}$ round, 16:00-22:00

Closing ceremony and prizegiving, 22:30

(venue to be announced)

Our hosts are attempting to attract Gary Kasparov to Madrid to give a simultaneous exhibition against as many of the programs as wish to play. If this materializes it will probably take place on the evening of Sunday November $22^{\text {nd }}$.

All events will take place in the Escuela Universitaria de Informática, unless otherwise stated. 
The ICCA will be making a block booking at a suitable hotel for the participants and officials. It is possible that we may be able to arrange for some spectators to take advantage of our special rates at the same hotel. Anyone interested should telephone or fax me around the beginning of November.

\section{Provisional list of entries}

Unfortunately, the reigning World Champion, DEEP THOUGHT, will not be participating in Madrid. Their team is working flat out on a new-generation chip and cannot afford the time to participate this year. The positive side of this decision is that there will be a new World Champion.

As of October $9^{\text {th }}$ there are 16 definite entries and two more probable. The "probables" are B* HITECH (USA), an improved version of Hans Berliner's renowned program, and the German PC-based program FRITZ.

The list of entries so far is:

\begin{tabular}{|c|c|c|c|}
\hline Program & Programmer(s) & Country & Hardware \\
\hline CENTAUR & $\begin{array}{l}\text { Viktor Vikhrev } \\
\text { \& Alexei Manjakhin }\end{array}$ & Russia & $\mathrm{PC}$ \\
\hline CHESS GENIUS 1.0 & $\begin{array}{l}\text { Richard Lang } \\
\text { \& Ossi Weiner }\end{array}$ & $\begin{array}{l}\text { UK } \\
\text { \& Germany }\end{array}$ & PC \\
\hline CUMULUS & $\begin{array}{l}\text { Jean-Christophe } \\
\text { Weill }\end{array}$ & France & $\mathrm{PC}$ \\
\hline ECHEC & Marc Baudot & France & $\mathrm{PC}$ \\
\hline HIARCS & Mark Uniacke & UK & Sun Sparc 2 \\
\hline $\begin{array}{l}\text { KASPAROV } \\
\text { Sparc module }\end{array}$ & $\begin{array}{l}\text { Dan and Kathe } \\
\text { Spracklen }\end{array}$ & USA & $\begin{array}{l}\text { Saitek } \\
\text { Leonardo }\end{array}$ \\
\hline LACHEX & Burton Wendroff & USA & Cray \\
\hline M_CHESS & Marty Hirsch & USA & PC \\
\hline MIRAGE & $\begin{array}{l}\text { Juri Shpeer } \\
\text { \& Vladimir Rybinkin }\end{array}$ & Russia & PC \\
\hline NIGHTMARE & $\begin{array}{l}\text { Reinhold Gellner } \\
\text { \& Gaby von Rekowski }\end{array}$ & Germany & $\mathrm{PC}$ \\
\hline NIMZO & $\begin{array}{l}\text { Ch. Donninger } \\
\text { \& A. Kure }\end{array}$ & Austria & PC \\
\hline PANDIX & $\begin{array}{l}\text { Gyula and Zsuzsa } \\
\text { Horvath }\end{array}$ & Hungary & PC \\
\hline PROCHESS & Tom Pronk & Netherlands & $\mathrm{PC}$ \\
\hline REBEL & Ed Schröder & Netherlands & ARM2 \\
\hline RISC 2500 & Johan de Koning & Netherlands & $\mathrm{PC}$ \\
\hline ULYSSES & $\begin{array}{l}\text { Ulf Lorenz } \\
\& \text { Valentin Rottmann }\end{array}$ & Germany & Parsytec T-800 \\
\hline WOODPUSHER 2 & John Hamlen & UK & $\mathrm{PC}$ \\
\hline ZUGZWANG & Rainer Feldmann & Germany & Parsytec \\
\hline
\end{tabular}

